\title{
Improving The Expressive Languages of Deaf Children Using Reflective Maternal Method (RMM)
}

\author{
Mariatul Qiftiah, Eviani Damastuti \\ Special Education Study Program \\ Universitas Lambung Mangkurat \\ Banjarmasin, Indonesia \\ mariatulqiftiah167@gmail.com
}

\author{
Chairil Faif Pasani \\ Mathematics Education Study Program \\ Universitas Lambung Mangkurat \\ Banjarmasin, Indonesia \\ chfaifp@ulm.ac.id
}

\begin{abstract}
People are able to communicate with other people using language meanwhile deaf people cannot do it. It is caused by the lack of expressive language affected by the loss of sense of hearing that obstructs the way they communicate. In this study, the research participants were deaf children who have hindrances to communicate using expressive language. In order to improve the expressive language of the deaf children, Reflective Maternal Method (RMM) was applied. This study used a quantitative approach using SSR plan with A-B-A design with deaf students in TKLB B/C Dharma Wanita Banjarmasin with A initial. The result of the study showed that there was an improvement in the expressive language of deaf children using the reflective maternal method. Before the children were given the treatment, the average score was only $60 \%$, and after given the intervention, it showed progress $28.6 \%$. After the next intervention, there was an improvement in children's expressive language, which was $100 \%$. From these results, it can be concluded that the Reflective Maternal Method (RMM) can improve the expressive language of deaf children.
\end{abstract}

Keywords-expressive language, deaf children, reflective maternal method.

\section{INTRODUCTION}

Education is a teaching and learning process that can bring changes. Well-developed education is expected to be able to produce qualified nation's future generation who are able to adapt to living in a society, nation, and state. According to [1] Article 32 Paragraph 1, it is stated that special education is an education for students who have difficulty in following the learning process because of physical, emotional, mental, and social abnormality, and/ or having potential intelligence and special talents. The purpose of special education is to develop a child's life as a good individual and can socialize in society. Special education consists of TKLB (kindergarten) until SMALB (secondary school).

Children with special needs are also defined as children who experience physical, language and speech, intelligence, emotional and social disturbances so that they need special learning. The term is used as a variation of special needs. According to [2], disability is a limitation or lack of ability (resulting from an impairment) to display activities in accordance with the rules or still within normal limits which are usually used at an individual level. Broadly speaking, children with special needs can be grouped into two types, namely children with permanent special needs, and children with temporary special needs. Children with temporary special needs are children who experience emotional disturbances such as trauma, while children with special needs permanently are children with visual impairment, autism, deafness, and mental retardation.

One of the kinds of children with permanent special needs is a deaf child. A deaf child is someone who experiences obstacles in the process of speech and language caused by hearing abnormalities. As a result of the obstruction of speech and language development, deaf children will experience delays and difficulties in matters related to communication. The main obstacle of deafness in the communication process is because of the lack of vocabulary and poor fluency in the process of speaking. This is due to the organs that are important for understanding language, namely the sense of hearing, does not function properly. That condition causes the deaf child having difficulty in the process of adjusting to his/her surroundings. To overcome various problems caused by disability, especially in developing language skills in deaf children, children should often socialize with the environment surrounding.

According to [3] "language" is a mean of communication between members of society in the form of sounds or signs or symbols issued by people to convey their ideas to other people". Through language, a human can communicate with the surrounding can interact between one another and all activities in the community involving language as the main tool.

From the result of observation at TKLB B/C Dharma Wanita Banjarmasin, it was found that deaf children cannot communicate using proper language; children are only able to communicate using mother sign language. Limitations experienced by deaf children in expressive language greatly inhibit children in communicating with the surrounding environment. Expressive language is a person's ability to communicate using body movements. Interference in expressive language is the difficulty in expressing what someone wants to convey to others. One of the methods of teaching that can develop language skills of deaf children is by using the Reflective Maternal Method (RMM). 
The Reflective Maternal Method (RMM) is a teaching method developed by Uden from an educational institution of children, St. Michielgestel Netherland. Ref. [4] explained that the main principle of RMM is "what do you want to say, say this". This method is also often called the method of conversation between mother and child (baby). The Reflective Maternal Method (RMM) is expected to help deaf children to facilitate communication with others, to practice the development of children's speech, to reduce the use of sign language, and to deliver the language more systematically.

In Indonesia, only several schools have implemented the Reflective Maternal Method for deaf children, especially in Banjarmasin, South Kalimantan. There are no schools that specifically apply this method. Therefore, the researchers want to apply this method at the TKLB B/C Dharma school in Banjarmasin so that deaf children are easier to communicate with the surrounding environment.

\section{METHOD}

This study used a quantitative approach aiming to obtain the data needed by looking at the results of a treatment. It utilized the SSR method (Single Subject Research) with A-B-A design to show the results of a treatment (intervention) for children. The subjects in this study were deaf children at TKLB B/C Dharma Wanita Banjarmasin who experienced obstacles in communicating using expressive language. The data was collected using a permanent product with the type of dependent variable size on data collection using percentages. Percentage refers to the number of occurrences of a behavior. The research instrument used in this study was a test. The data was analyzed by finding out the effect of an intervention on the behavior of the subject's behavior that was desired to be changed. The researchers used a visual analysis technique in which the data analysis is in conditions and between conditions.

\section{RESULTS AND DISCUSSION}

TABLE I. ThE DATA Results on EXPRESSIVE LANGUAGE IN BASELINE PHASE 1 (A1)

\begin{tabular}{|c|c|c|c|c|c|}
\hline $\begin{array}{l}\text { Se } \\
\text { ssi } \\
\text { on }\end{array}$ & Date & $\begin{array}{l}\text { Maximu } \\
\text { m Score }\end{array}$ & $\begin{array}{l}\text { Obtained } \\
\text { Score }\end{array}$ & Percentage & $\begin{array}{l}\text { Mean } \\
\text { level }\end{array}$ \\
\hline 1 & $\begin{array}{l}21-03- \\
2018\end{array}$ & 20 & 1 & $5 \%$ & \multirow{5}{*}{$60 \%$} \\
\hline 2 & $\begin{array}{l}22-03- \\
2018\end{array}$ & 20 & 2 & $10 \%$ & \\
\hline 3 & $\begin{array}{l}23-03- \\
2018\end{array}$ & 20 & 3 & $15 \%$ & \\
\hline 4 & $\begin{array}{l}24-03- \\
2018\end{array}$ & 20 & 1 & $5 \%$ & \\
\hline 5 & $\begin{array}{l}26-03- \\
2018\end{array}$ & 20 & 1 & $5 \%$ & \\
\hline
\end{tabular}

Based on Table 1 , the baseline phase $1\left(\mathrm{~A}_{1}\right)$ shows an average result of $60 \%$ from 5 sessions. From one to five sessions, the results tend to fluctuate because the children have not been able to communicate with expressive language. It is caused by the lack of enthusiasm in learning and often disturbed by friends. According to [5], expressive language is the ability of a person to convey a message using gestures.
TABLE II. ThE DATA RESUlts ON EXPRESSIVE LANGUAGE IN INTERVENTION PHASE (B)

\begin{tabular}{|l|l|l|l|l|l|}
\hline $\begin{array}{c}\text { Sessi } \\
\text { on }\end{array}$ & Date & $\begin{array}{c}\text { Maxim } \\
\text { um } \\
\text { Score }\end{array}$ & $\begin{array}{c}\text { Obtained } \\
\text { Score }\end{array}$ & Percentage & $\begin{array}{c}\text { Mean } \\
\text { level }\end{array}$ \\
\hline 6 & $27-03-2018$ & 20 & 4 & $20 \%$ & \\
\cline { 1 - 5 } & $28-03-2018$ & 20 & 4 & $20 \%$ & \multirow{2}{*}{$28,6 \%$} \\
\cline { 1 - 5 } & $29-03-2018$ & 20 & 7 & $35 \%$ & \\
\cline { 1 - 5 } 9 & $02-04-2018$ & 20 & 9 & $45 \%$ & \\
\hline 10 & $03-04-2018$ & 20 & 10 & $50 \%$ & \\
\hline 11 & $04-04-2018$ & 20 & 10 & $50 \%$ & \\
\hline 12 & $05-04-2018$ & 20 & 10 & $50 \%$ & \\
\hline
\end{tabular}

Based on Table 2, it is seen that the result is $28.6 \%$ of the 7 sessions conducted. At this stage, the intervention is given to children using the Reflective Maternal Method (RMM). During this intervention phase, the children are very excited about learning because the children are very happy with the use of the method applied by the researcher. Children begin to be able to express a few words well which is in accordance with what was stated in [4] explains that the main principle of RMM is "what do you want to say, say this".

Children experience an increase in the use of expressive language. It proves that the Reflective Maternal Method (RMM) can improve the expressive language of deaf children.

TABLE III. The DATA Results On EXPRESSIVE LANGUAGE IN BASELINE PHASE 2 (A2)

\begin{tabular}{|c|c|c|c|c|c|}
\hline Session & Date & $\begin{array}{c}\text { Maximum } \\
\text { Score }\end{array}$ & $\begin{array}{l}\text { Obtained } \\
\text { Score }\end{array}$ & Percentage & $\begin{array}{c}\text { Mean } \\
\text { level }\end{array}$ \\
\hline 13 & $\begin{array}{l}06- \\
04- \\
2018\end{array}$ & 20 & 11 & $55 \%$ & \multirow{5}{*}{$100 \%$} \\
\hline 14 & $\begin{array}{l}07- \\
04- \\
2018\end{array}$ & 20 & 12 & $60 \%$ & \\
\hline 15 & $\begin{array}{l}09- \\
04- \\
2018\end{array}$ & 20 & 11 & $55 \%$ & \\
\hline 16 & $\begin{array}{l}\text { 10- } \\
04- \\
2018\end{array}$ & 20 & 12 & $60 \%$ & \\
\hline 17 & $\begin{array}{l}11- \\
04- \\
2018\end{array}$ & 20 & 12 & $60 \%$ & \\
\hline
\end{tabular}

Based on Table 3, the obtained result is $100 \%$ of 5 sessions. At this stage, the children experienced improvement compared to the previous stage. They have been able to express some of what they want to convey well, this is because researchers are responsive in what the child wants to convey. This theory is in line with what was revealed in [6] that Reflective Maternal Method (RMM) is a method of teaching using conversation to improve children's language skills.

\section{CONCLUSION}

The implementation of Reflective Maternal Method (RMM) can be used to improve the ability to use expressive language by deaf children at TKLB B/C Dharma Wanita Banjarmasin. 


\section{REFERENCES}

[1] Republic of Indonesia. Undang-Undang Republik Indonesia Nomor 20 Tahun 2003 tentang Sistem Pendidikan Nasional. Jakarta: Sekretariat Negara, 2003

[2] Organisation mondiale de la santé and World Health Organization. International Classification of Functioning, Disability, and Health: Children \& Youth Version: ICF-CY. World Health Organization, 2007.

[3] W. Setyaningsih, "Peningkatan kemampuan bahasa reseptif dan ekspresif tingkat kata dengan metode multisensori di SLBN Surakarta,' Jurnal Ilmu Kesehartan, vol. 2, no. 2, 2013. Available: http://jurnal. poltekkes-solo.ac.id/index.php/Int/article/view/73 [Accessed January 20, 2018 .
[4] H. Elkhusna, "Gambaran dari dampak penggunaan metode maternal reflektif (MMR) terhadap perkembangan bahasa dan komunikasi pada murid tunarungu kelas VI SLB B Karnnamonohara," Thesis, Universitas Santa Dharma Yogyakarta, Yogyakarta, Indonesia, 2013.

[5] F. N. Khairin, "Pengaruh Terapi Musik Mozart Dalam Meningkatkan Kemampuan Bahasa Reseptif Dan Ekspresif Pada Anak Autistik Di SLB BC Pambudi Dharma 1 Cimahi," Thesis, Universitas Pendidikan Indonesia, Bandung, Indonesia, 2012. Available: http://repository. upi.edu/10749/ [Accessed January 15 2018]

[6] S. Kuwati, "Penerapan Metode Maternal Reflektif untuk meningkatkan prestasi belajar bidang studi Bahasa Indonesia bagi anak tunarungu kelas II SLB Negeri Wiradesa Pekalongan," Thesis, Universitas Sebelas Maret, Surakarta, Indonesia, 2009. Available: https://eprints.uns. ac.id/5802/ [Accessed January 15, 2018] 